\title{
Preference Čechů pro adaptační opatření ke zmírnění dopadů povodní a sucha
}

IVA ZVĚŘINOVÁ, MILAN ŠČASNÝ, ZUZANA RAJCHLOVÁ

Klíčová slova: adaptace na změnu klimatu - technická opatření - prírodní opatření - výběrový experiment - ochota platit

\section{SOUHRN}

Cílem výzkumu je zjistit postoje a preference obyvatel ČR vưči adaptačním opatřením na snížení dopadů povodní a sucha. Na jaře 2016 jsme uskutečnili dotazníkové šetření na reprezentativním vzorku obyvatel ČR (3 666 respondentů). Více než polovina dotázaných očekává, že jejich domácnost bude v př́ítích 10 letech častěji vystavena dopadi̊m sucha a vin horka. Na národní úrovni respondenti nejčastěji podporovali změnu způsobu hospodaření v lesích (72 \%) a zemědělské půdě (69 \%) a využívání odpadní a deštové vody (63\%). Velmi populární je také vytváření mokřadů. Nejkritičtěji se vyjadřovali k zavedení daní či poplatků. Češi jsou ochotni i nést část nákladů na snížení dopadů sucha a povodní. V průměru jsou ochotni zaplatit měsičně za domácnost 1000 Kč v prípadě adaptačních opatření na snížení dopadů sucha nebo 923 Kč v případě povodní. Respondenti jsou ochotni nést náklady technických opatření, ale jejich príijatelnost klesá, jak se zvyšuje jejich podíl na úkor opatření prírodě blízkých.

\section{ÚVOD}

Adaptační opatření, která by mohla pomoci se přizpůsobit změnám klimatu a jejich důsledkům, jsou $v$ současnosti navrhována a zaváděna na národní a regionální úrovni, dotknou se však i jednotlivců a jejich každodenních životů. Občané sami budou pravděpodobně přispívat k realizaci některých opatření, poprípadě provádět vlastní, individuální, kroky k minimalizaci dopadů na svůj život a majetek. Realizace adaptačních opatření proto do značné míry závisí na názoru a reakci veřejnosti. Podpora veřejnosti může také přispět k implementaci politik a ovlivnit ochotu politiků príimout konkrétní opatření [1].

Z těchto důvodů jsme uskutečnili na jaře 2016 dotazníkové šetření obyvatel ČR, v rámci kterého jsme zkoumali právě postoje a preference vưči adaptačním opatřením. Zjišťovali jsme, jaké živelné pohromy Češi očekávají, jaké očekávají důsledky změny klimatu, jaká veřejná a individuální adaptační opatření upřednostňují, jaké preferují plány na přizpưsobení se změně klimatu a jestli by byli ochotni nést náklady zavedení takového plánu.

\section{MATERIÁL A METODY}

V príspěvku analyzujeme data z dotazníkového šetření, které bylo provedeno na reprezentativním vzorku obyvatel ČR prostřednictvím webového dotazníku zaslaného respondentům v aktivně spravovaném panelu, v němž je identita dotazovaných pravidelně ověřována. Bylo celkem získáno 3666 platných dotazníků od obyvatel starších 18 let. Vzorek je reprezentativní pro 8 regionů (NUTS 2) na základě kvótních charakteristik, konkrétně velikost místa bydliště, věk, pohlaví a vzdělání.
Všech respondentů jsme se ptali, jak často budou oni a jejich domácnost během prriśstích 10 let vystaveni dopadům živelních pohrom a jak závažné dopady živelních pohrom očekávají. Vnímání četnosti a závažnosti dopadů živelních pohrom bylo měřeno s využitím sedmibodové Likertovy škály a byla nabídnuta možnost, že se živelní pohroma respondentovy domácnosti netýká. Na obr. 2 uvádíme podíly z dotázaných, kteří uvedli, že se jich živelní pohroma týká.

Všichni dotázaní také zodpovídali otázku, jaké budou důsledky změny klimatu do roku 2040, nebudou-li podniknuty žádné kroky vedoucí k zmírnění změny klimatu (žádná nová účinná opatření). Konkrétně byli požádáni uvést na škále od 1 do 7, do jaké míry souhlasí s tím, že nastanou různé situace (např. budou častější období sucha, zvýší se produkce potravin a další). V textu uvádíme podíly ze všech odpovědí.

Účastníci výzkumu byli následně náhodně rozděleni do tři podskupin, z nichž každá obdržela jinou verzi výběrového experimentu a hodnocení jiných adaptačních opatření. V tomto článku analyzujeme data ze dvou podskupin, z nichž první podskupina obdržela adaptační plány snižující dopady povodní a druhá podskupina obdržela opatření snižující dopady sucha. $Z$ tohoto dưvodu je počet respondentů, kteři volili v experimentu na sucho, 1213 a na povodně 1 160. Třetí podskupina volila plány snižující dopady sucha i povodní dle závažnosti jejich dopadů a podílů ohrožených obyvatel, ale výsledky tohoto výběrového experimentu nejsou v tomto článku prezentovány (výsledky Ize najít ve výzkumné zprávě [2]).

Pro hodnocení různých adaptačních opatření jsme se respondentů ptali, jestli by zavedli či nezavedli rưzná opatření na škále od 1 do 7, kdy 1 znamenala „rozhodně zavést" a 7 "rozhodně nezavést", nebo mohli vybrat možnost "nevím”.

Preference občanů byly zkoumány prostřednictvím výběrového experimentu, $\checkmark$ rámci kterého respondenti volili mezi různými adaptačními plány, které se lišily podílem prírodních a technických opatření, druhem nestavebních opatření, podílem opatření, která přispějí ke zmírnění klimatu, a také vyvolanými náklady, které by domácnosti respondentů musely nést prì jejich zavedení.

Respondentům byla volba podoby adaptačního plánu $v$ dotazníku představena jako jistá forma referenda, v rámci kterého bychom rádi zjistili, jaký plán by lidé upřednostňovali. Dále bylo vysvětleno, že probíhá diskuse mezi odborníky a politiky, jaký by Národní akční plán adaptace na změnu klimatu měl být, a že tento dokument bude schválen vládou a bude stanovovat výši finančních prostředků, které by se měly vynakládat na opatření pro přizpůsobení se změnám klimatu. V době realizace šetření se Národní akční plán adaptace na změnu klimatu teprve připravoval, takže mohl být využit pro scénář výběrového experimentu. Národní akční plán adaptace na změnu klimatu byl schválen Vládou ČR 16. ledna 2017 [3]. 


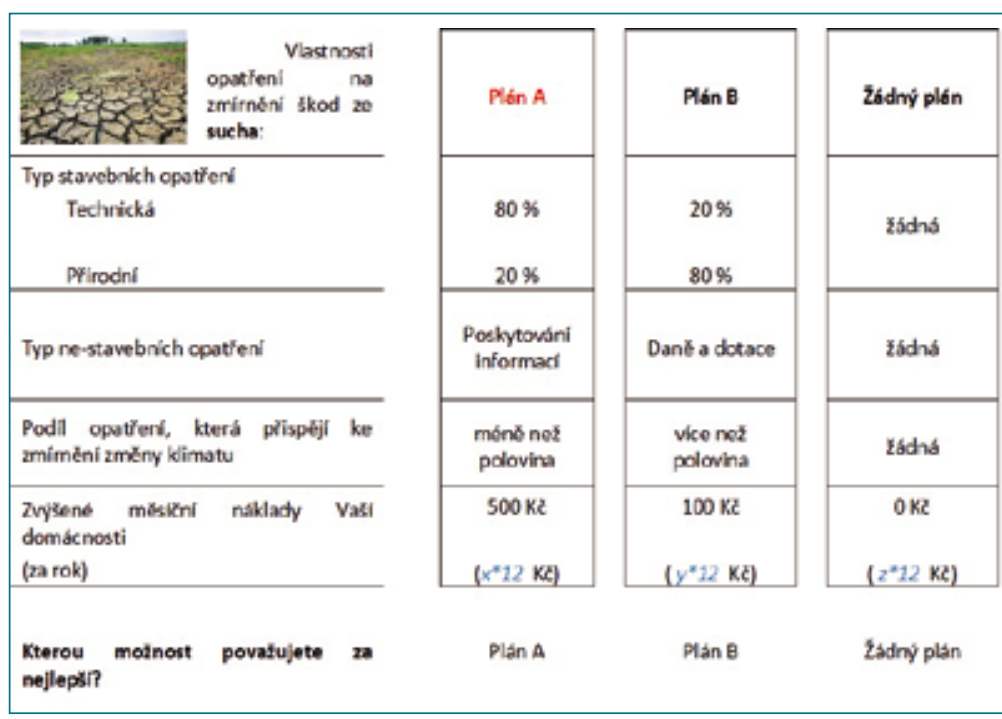

Obr. 1. Ukázka výběrové karty pro výběrový experiment zaměřený na typy adaptačních opatření zmírňujicí škody ze sucha

Fig. 1. Example of a choice card - choice experiment focused on types of adaptation measures to limit drought damage

Zvýšení nákladů respondenta bylo v dotazníku zdůvodněno jako zvýšení cen pitné vody a výrobků v důsledku toho, že stát, správy povodí a společnosti, které dodávají pitnou vodu, budou muset provést nová opatření. Zavedením poplatků za zastavování ploch nebo za vysoké odběry vody by se podnikům zvýšily náklady na výrobu. Všechny tyto náklady by se z části promítly do zvýšení cen pitné vody a výrobků, které běžně všechny domácnosti platí.

Cílem výběrového experimentu je zjistit preference respondentů ohledně typů adaptačních opatření. Konkrétně jsme vyzvali respondenty volit mezi plány, které se lišily:

— podílem technických a prírodě blízkých opatření (100\%, $80 \%, 60$ \%, 40 \% technických, prričemž součet podílu obou byl vždy $100 \%$ ),

- dodatečnými nestavebními opatřeními (poskytování informací, územní plánování, daně a dotace, pojištění, nebo žádná),

— podílem opatření, která přispějí k řešení snižování emisí skleníkových plynů (méně než polovina, polovina nebo většina projektů)

- a náklady pro domácnost respondenta.

Před volbou plánu jsme respondentům v dotazníku vysvětlili, že bychom chtěli zjistit, jaké druhy opatření považují za nejlepší. Výběrovou kartu pro opatření na zmírnění škod ze sucha ilustruje obr. 1.
Respondenti volili mezi dvěma plány a žádnými opatřeními celkem pětkrát a alternativy byly popsány efektivním designem rozděleným do 15 bloků. Charakteristiky plánů a úrovně, které se respondentům zobrazovaly, jsou shrnuty $v$ tabulce 1 .

Data byla statisticky a ekonometricky analyzována. Užité byly zejména modely diskrétní volby. Pro tento príspěvek byla ochota platit odhadnuta multinomiální podmíněnou logistickou regresí. Teoretickým základem ekonometrického modelu je model náhodného užitku („rrandom utility model“) [4].

Pro analýzu dat z výběrového experimentu jsme identifikovali protestující, kteři vždy ve výběrovém experimentu zvolili „žádný plán“ a zároveň projevovali nesouhlas s představeným scénářem zavádění Národního akčního plánu. V př́padě sucha protestovala necelá $3 \%$ respondentů, v prípadě povodní pouze okolo $2 \%$. Pouze $1 \%$ respondentů nevěřilo, že budou výnosy zvýšení cen skutečně využity na realizaci plánu. Ekonometrické modely jsou v tomto článku pak odhadnuté s vyloučením těchto protestních voleb. Důvodem pro vyloučení protestujících je, že vlastně neznáme jejich preferenci, tedy že $v$ prípadě jiného scénáře by mohli volit adaptační plán nebo nikoliv.

Z analýz jsme naopak nevyloučili odpovědi respondentů, kteří uvedli, že nebudou oni ani jejich domácnost během prrištích 10 let vystaveni dopadům živelních pohrom. Cílem bylo totiž zjistit preference obecné populace pro adaptační opatření, která budou financována podle Národního plánu v celé České republice. Důsledky zavedení adaptačních plánů se budou týkat všech obyvatel, nikoliv jen těch, kterých se pohromy bezprostředně týkají. Pokud respondenti, kteří nejsou vystaveni dopadům pohrom, nechtěli přispívat, zvolili „žádný plán", což považujeme za platnou volbu. Pouze velmi malý podíl respondentů (0,3 \% respondentů, kterým byl príǐazen výběrový experiment na sucho a 2,4 \% v prípadě výběrového experimentu na povodně) uvedl jako důvod volby „žádného plánu", že domácnost není ohrožena suchem či povodněmi. Další informace k dotazníkovému šetření a další analýzy dat včetně výběrových experimentů jsou k dispozici ve zprávě z výzkumu [2].

\section{VÝSLEDKY A DISKUSE}

Většina respondentů, kterých se týkají povodně (60\%), vichřice či krupobití, sesuvy nebo sesedání půdy (64 \%) předpokládá, že jejich domácnost bude těmto pohromám $\vee$ príštích deseti letech vystavena stejně často jako $v$ současnosti. Co se týče závažnosti, tak u povodní, vichřic a krupobití a sesuvu nebo sesedání půdy jedinci z více jak 70 \% předpokládají, že dopady budou stejně závažné jako doposud. Závažnější důsledky spojují s vinami horka a sucha, kdy u horka 42 \% a u sucha téměř 50 \% dotazovaných předpokládá zhoršení dopadů na svou domácnost. Podle 59 \% respondentů budou jejich domácnosti častěji vystaveny suchu a podle 56 \% respondentů domácnosti budou častěji vystaveny vinám horka (viz obr. 2).

Tabulka 1. Atributy a úrovně výběrového experimentu

Table 1. Discrete choice experiment - the attributes and their levels

Charakteristiky plánů

Úrovně adaptačních plánů

Úrovně žádného plánu

Typ stavebních opatření Technická

$100 \%, 80 \%, 60 \%, 40 \%$

žádná

Přírodní $60 \%, 40 \%, 20 \%, 0 \%$

Typ nestavebních opatření poskytování informací, územní plánování, daně a dotace, pojištění, nebo žádná

Žádná

Podíl opatření, která přispějí ke zmírnění změny klimatu

méně než polovina, polovina, více než polovina

žádná

Zvýšené měsíční náklady domácnosti (za rok)

50 Kč, 100 Kč, 200 Kč, 300 Kč, 500 Kč

$0 \mathrm{Kč}$ 
Častější výskyty sucha v budoucnu respondenti dále spojují se změnami klimatu. $V$ důsledku změny klimatu přibližně dvě třetiny z celého vzorku obyvatel (62 \%) očekávají do roku 2040 častější období sucha ve svém regionu a téměř polovina ze všech respondentů rovněž očekává úbytek biodiverzity. Více než třetina předpokládá celkové zhoršení životní úrovně obyvatel (35\%) a častější povodně (29\%).

Podobně jako Češi také většina Italů (62 \%) očekává do roku 2040 častější období sucha v důsledku klimatických změn. Naopak pouze 37 \% Britů má stejné očekávání. Povodně však očekává $41 \%$ Britů a $51 \%$ Italů [5]. Bouře a povodně, nepredvídatelnost počasí, sucho a vlny veder, ale i zvýšení hladiny moří jsou nejčastěji jmenované očekávané dopady změny klimatu také např́iklad ve studii provedené ve Francii, Německu, Norsku a Velké Británii [6].

Mezi opatřeními zmírňujícími dopady sucha v kraji získalo největší podporu opatření, které by do kraje přineslo zlepšení a vytváření více zelených a vodních ploch (71\%). Dále by jedinci v nadpoloviční většině uvítali informace o způsobech chování během sucha (58 \%), budování malých vodních nádrží a rybníků (54%) nebo regulaci spotřeby vody v období sucha (53\%). Nejvíce kriticky se respondenti stavěli k tzv. zeleným střechám na budovách, které by zavedlo pro snížení sucha jen $35 \%$ dotázaných a jsou tak nejméně preferovaným typem opatření.

Také na národní úrovni respondenti pro snižení negativních důsledků sucha podporovali zejména prírodní opatření (obr. 3), konkrétně nejčastěji změnu způsobu hospodaření v lesích (72\%) a zemědělské půdě (69\%). Třetím nejvíce podporovaným opatřením je poté využívání odpadní a deštové vody. Nejkritičtěji se respondenti vyjadřovali naopak k opatření, které by se jich mohlo dotýkat prímo a to daně či poplatky za nadměrnou spotřebu vody. Toto opatření odmítá 30 \% dotázaných a přijalo by ho pouhých $18 \%$.

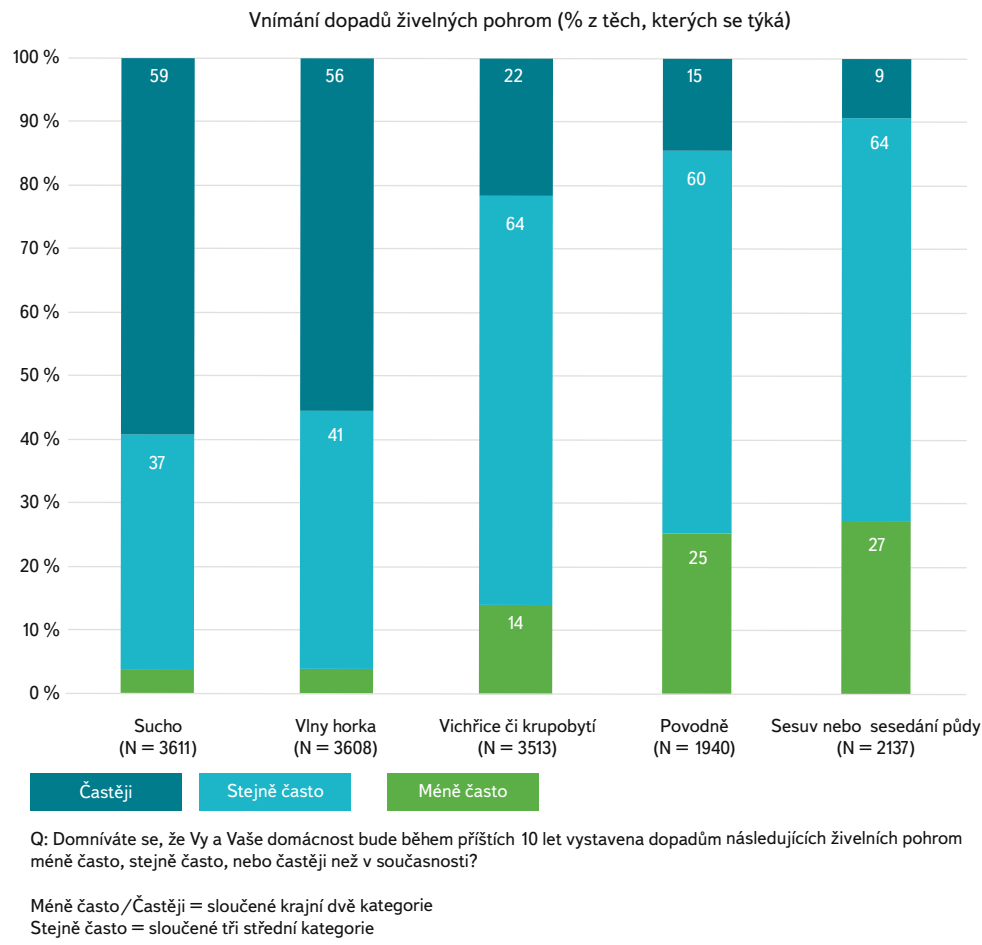

Obr. 2. Vnímání četnosti dopadů živelných pohrom na domácnosti respondentů, kteří se vyjádřili, že se jich dané pohromy týkaji

Fig. 2. Perception of the frequency of natural disasters impacts on households of respondents who have expressed their concern about the disasters

Tabulka 2. Odhad volby konkrétních opatření na snižení škod z povodní a sucha, multinomální logistická regrese, po vyloučeni protestních odpovědi Table 2. Choice of specific measures to limit damages from floods and droughts, multinomal logistic regression, after exclusion of protest responses

\section{SUCHO}

\begin{tabular}{|c|c|c|c|c|c|}
\hline & koef. & t stat & $p$ value & WTP & koef. \\
\hline adaptace & 2,1995 & 26,9 & $<, 0001$ & 1,000 Kč & 2,4151 \\
\hline technické (\%) & $-0,015$ & $-14,54$ & $<, 0001$ & $-6,8$ Kč & $-0,015$ \\
\hline daně & $-0,0151$ & $-0,25$ & 0,8029 & * & $-0,0785$ \\
\hline pojištění & 0,1848 & 3,32 & 0,0009 & 84 Kč & $-0,0037$ \\
\hline plánování & 0,0899 & 1,34 & 0,1795 & * & 0,0106 \\
\hline informace & 0,0366 & 0,48 & 0,6337 & $*$ & $-0,0619$ \\
\hline mitigace (střední) & 0,0456 & 1,05 & 0,2956 & $*$ & $-0,0087$ \\
\hline mitigace (velké) & 0,0671 & 1,38 & 0,1664 & $*$ & 0,0995 \\
\hline náklady & $-0,0022$ & $-17,81$ & $<, 0001$ & & $-0,0026$ \\
\hline No respondentů & 1213 & & & & 1160 \\
\hline No odpovědí & 6065 & & & & 5800 \\
\hline Log Likelihood & -6018 & & & & -5656 \\
\hline $\log L(0)$ & -6663 & & & & -6372 \\
\hline
\end{tabular}

POVODNĚ

Poznámka: * Koeficient u daného atributu není statistický rozdílný od nuly, a proto hodnota WTP není odvozena. 
Která z následujicích opatření zmírňujicí dopady sucha by podle Vás měla, nebo neměla být zavedena $v$ ČR?
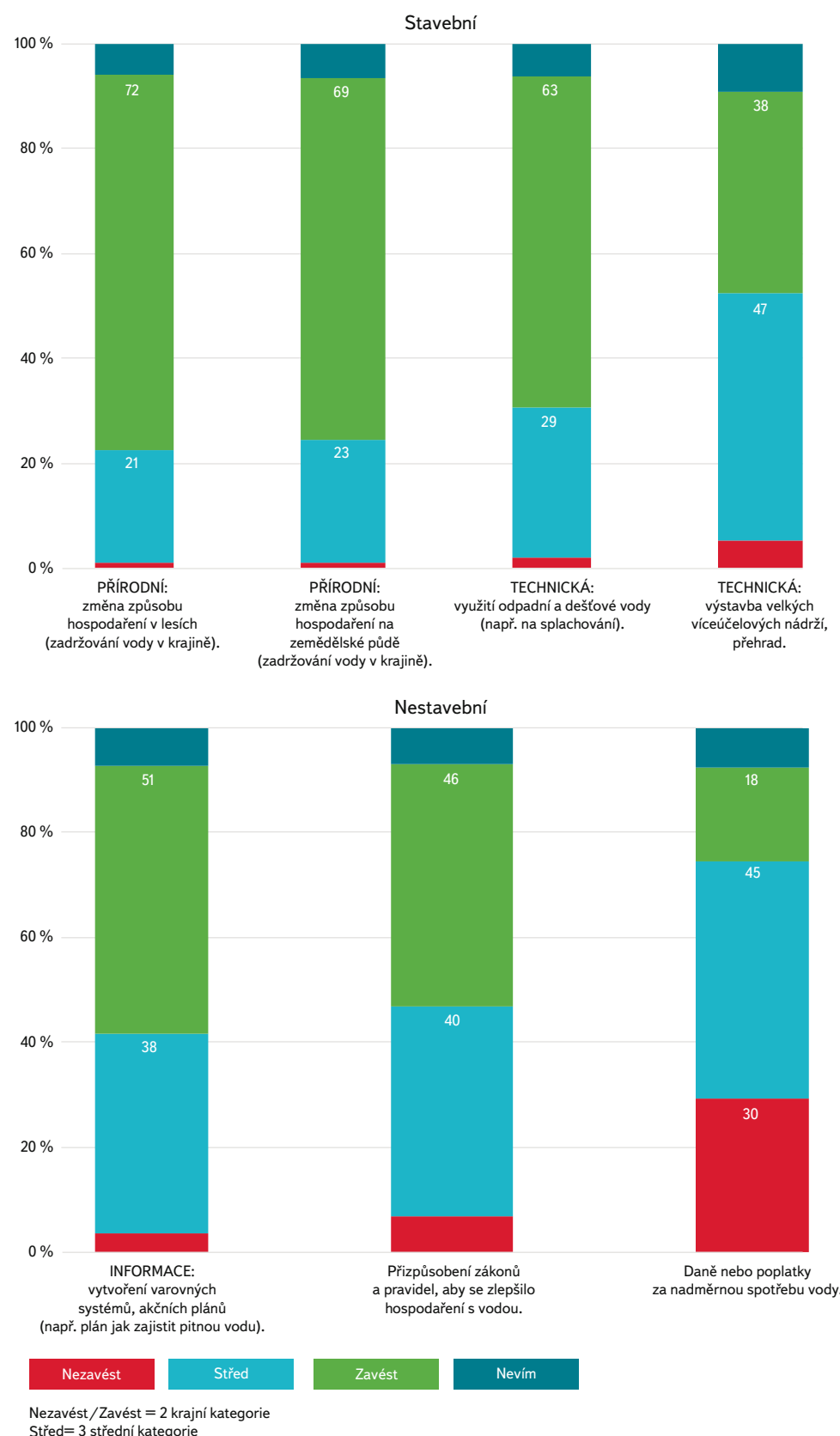

Střed $=3$ střední kategorie

Obr. 3. Vyjádření souhlasu či nesouhlasu se zavedením navrhovaných opatření zmírňující dopady sucha v ČR (\%; N = 1196)

Fig. 3. Agreement or disagreement with the implementation of proposed measures to limit negative impacts of drought in the Czech Republic (\%, N = 1196)

Vyšší preference prírodě blízkých opatření lze najít i ve studiích z jiných zemí $[5,7,8]$. Zahraniční výzkumy se však spíše zaměrují na preference určitých skupin obyvatel, např. farmářů $[9,10]$ či turistů [11], nebo jsou prováděny v jiném geografickém regionu, takže se orientují na jiné dopady změny klimatu, adaptační opatření a jejich kombinace [12]. Prezentovaná studie je výjimečná v tom, že se zaměřuje na preference obecné populace $v$ regionu, kde obdobná studie nebyla doposud provedena, a na balíček různých opatření.
Co se týče povodní, tak největší podíl respondentů na krajské úrovni upřednostňuje údržbu a čištění koryt řek či potoků (73 \%) a udržování a tvorbu zeleně, mokřadů a jezírek zachycujících vodu (71\%). Třetím nejpřijatelnějším opatřením pro respondenty bylo strategické plánování v povodích, které podpořilo více jak tři pětiny respondentů ( $66 \%$ ). Oproti tomu nejkritičtěji se respondenti vyslovili opět v případě tzv. zelených střech, které by i v tomto prípadě príijalo jen 35 \% dotázaných. Významně menší podíl by zavedl jednoduchá a známá opatření proti povodním jako pytlování a budování protipovodňových zábran (39\% a $47 \%$ ). Na celorepublikové úrovni jsou pro povodně nejvíce preferovaná stejná opatření jako pro sucho, i když opatření pro sucho a povodně byla hodnocena jinými respondenty (viz kapitola Materiál a metody).

Mezi opatřeními zmírňující dopady vin veder bylo nejpopulárnější pasivní chlazení veřejných budov, respektive izolace, žaluzie a rolety. Pro zavedení této možnosti bylo přes tři pětiny lidí (63\%). Nadpoloviční většina respondentů by podpořila plánování výstavby rozvoje (56 \%). Češi byli naopak kritičtí k aktivnímu chlazení veřejných budov, klimatizaci, kterou by nechtělo pořizovat $17 \%$ respondentů a pro zavedení bylo pouhých $25 \%$ jedinců. O něco lépe byla hodnocena klimatizace $v$ prostředcích hromadné dopravy, kterou by uvítalo $37 \%$ a nezavedlo $11 \%$ respondentů. V obou prípadech klimatizace se ale hodnocení koncentrovalo ve středové kategorii.

Češi jsou ochotni i nést část nákladů na opatření zmírňující dopady sucha a povodní. Na základě analýzy dat z výběrového experimentu jsme zjistili, že $\checkmark$ průměru jsou respondenti ochotni zaplatit za adaptační opatření 1000 Kč (sucho) nebo 923 Kč (povodně) měsíčně za domácnost (viz tabulka 2). Dotázaní silně preferují prírodě blízká opatření. Ochota platit se snižuje s každým procentem, o které jsou prírodě blízká opatření nahrazována technickými opatřeními (viz obr. 4). Například v prípadě podílu 50\% technických a 50\% prírodě blízkých opatření ochota platit za adaptační plány klesne na 660 Kč měsíčně za domácnost pro opatření na snižování dopadů sucha (1000-50*6.8 Kč) a na 640 Kč měsíčně za domácnost u protipovodňových opatření (923-50*5.7 Kč).

Porovnání výsledků z České republiky se zahraničím umožňuje výzkum realizovaný autory článku v České republice, Itálii a ve Velké Británii na vzorcích obyvatel ve věku 18-69 let [5]. V tomto výzkumu jsme se zaměřili na preference pro konkrétní adaptační opatření. Zachytávání deštové vody je jedno z nejvíce preferovaných opatření pro snížení dopadů sucha ve všech třech zemích. V České republice byla ochota platit za zachytávání deštové vody téměř stejně vysoká jako ochota platit za vytváření mokřadů, výstavbu malých vodních nádrží a rybníků, či za změny způsobu hospodaření na zemědělské půdě (403 až 447 Kč za jednotlivá opatření měsíčně za domácnost). Naopak ve Velké Británii je ze všech opatření nejvyšší ochota platit za výstavbu velkých přehrad. Nicméně i ve Velké Británii je vytváření mokřadů velmi oblíbené a ochota platit je jen o málo nižší než za přehrady. Italové upřednostňují před ostatními opatřeními nestavební opatření, zejména daňové úlevy na technologie šetřící vodu. Preference pro adaptační opatření ovlivňuje nejen typ opatření ale i vnímaná účinnost opatření a do jaké míry si lidé myslí, že jsou opatření zavedena [5].

Srovnání preferencí prírodních, strukturních, technických a měkkých opatření poskytuje také např. švýcarská studie [8], ve které jsou respondenti ochotní zaplatit za zvýšení zalesnění o 40 \% až 260 CHF na osobu za rok (cca 5800 Kč), ale je zřejmé, že design výzkumu byl jiný. Ochota platit za opatření proti suchu byla také zjištována v několika amerických výzkumech. Napríklad podle Wangové [13] je ochota platit za vodu 0,0120-0,048 USD/m³ $\left(0,23-0,9 \mathrm{Kč} / \mathrm{m}^{3}\right) \vee$ závislosti na závažnosti sucha. Podle Griffina a Mjeldeho [14] jsou respondenti ochotní zaplatit mezi 12,99 a 48,88 USD (460-1750 Kč), aby zamezili omezením způsobeným suchem. Další výzkum uvádí, že lidé jsou ochotni zaplatit za účet za vodu měsíčně o 11,60-16,90 USD (350-500 Kč) více, aby se vyhnuli snížení dodávek vody [15]. 


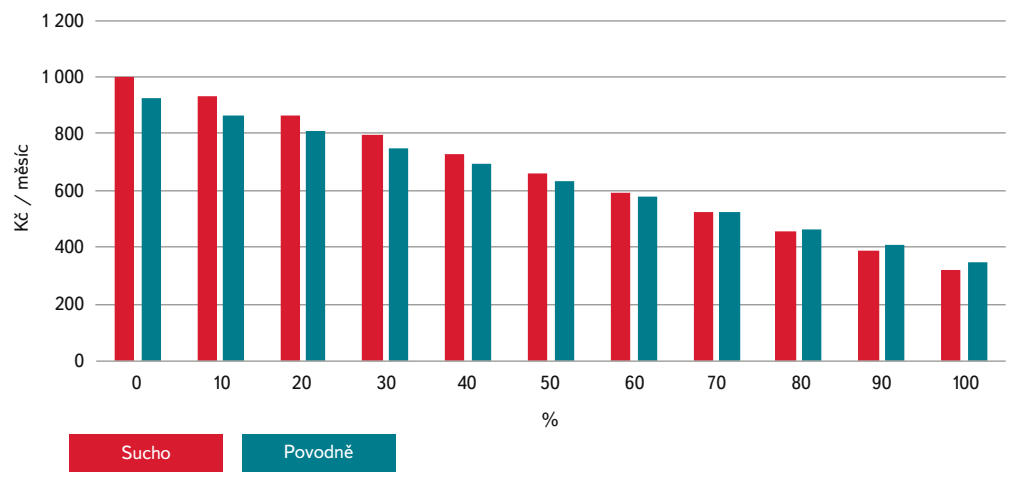

Obr. 4. Ochota platit za adaptační opatření (v Kč) v závislosti na podílu technických opatření (v procentech)

Fig. 4. Willingness to pay for adaptation measures (in CZK) depending on the share of technical measures (in percentage)

Z dodatečných strukturních opatření lidé upřednostňují pojištění škod ze sucha, zbylá dodatečná opatření nezvyšují ochotu platit za adaptační plány. Opatření na snížení škod z povodní, která mají vysoký potenciál snižení emisí skleníkových plynů (mitigace), jsou mírně preferována (ochota platit je 38 Kč měsíčně za domácnost). V ostatních případech snižování emisí skleníkových plynů pomocí adaptačních opatření nezvyšuje preferenci pro príjetí adaptačních opatření (viz tabulka 2).

\section{ZÁVĚR}

Z hlediska veřejnosti je nejpřijatelnější takový Národní akční plán adaptace na změnu klimatu, jehož cílem bude dosáhnout vysokého podílu prírodě blízkých opatření a bude podporovat pojištění škod ke zmírnění finančních dopadů sucha. Potenciál adaptačních opatření pro mitigaci je pro většinu respondentů nejdůležitější u protipovodňových opatření. V průměru jsou respondenti ochotni zaplatit za adaptační opatření 1000 Kč (sucho) nebo 923 Kč (povodně) měsíčně za domácnost. Například v případě podílu 50\% technických a 50\% prírodě blízkých opatření ochota platit za adaptační plány klesne na 660 Kč měsíčně za domácnost pro opatření na snižování dopadů sucha a na 640 Kč měsíčně za domácnost u protipovodňových opatření. Za predpokladu zavedení stejného podílu technických a prrírodě blízkých opatření je celková ochota platit za všechny domácnosti ČR za rok kolem 33 mld. Kč.

\section{Poděkování}

Výzkum, jehož výsledky jsou prezentovány $v$ tomto přispěvku, byl realizován v rámci rešení projektů Podpora výměny informací o dopadech změny klimatu a adaptačních opatřenína národní a regionální úrovni (EHP-CZ02-OV-1-011-2014) financovaného z EHP fondů 2009-2014 - programu CZ02 - Životni prostředí, GEMCLIME - Globální excelence $v$ modelování klimatu a energetiky financovaného z programu Horizont 2020 Evropské komise (H2020-MSCA-RISE-2015) a Ekonomie energetiky a politiky životního prostředi Univerzity Karlovy (PRIMUS/17/HUM/16).

Příspěvek byl publikován ve sborníku konference Vodní nádrže 2017, ISBN 978-80-905368-5-2.

\section{Literatura}

[1] STEG, L., DREIJERINK, L., and ABRAHAMSE, W. Why are Energy Policies Acceptable and Effective? Environment and Behavior [online], 2006, vol. 38, No. 1, p. 92-111. ISSN 0013-9165, 1552-390X. Dostupné z: doi:10.1177/0013916505278519

[2] ŠČASNÝ, M., ZVĚŘINOVÁ, I., MÁCA, V., MARTÍNKOVÁ, Z. a HAVRÁNEK, M. Jaká adaptační opatřeni Češi uprednostňují? Výzkumná zpráva z dotazníkového šetřeni postojů a preferencí vůči adaptačním opatřením. Praha: Univerzita Karlova, Centrum pro otázky životního prostředí, 2016, 83 s. Dostupné z: https:/l www.czp.cuni.cz/czp/images/2016/KLIMA.pdf

[3] MŽP. Národní akční plán adaptace na změnu klimatu, 2017. Dostupné z: https://www.mzp.cz/ C1257458002FODC7/cz/narodni_akcni_plan_zmena_klimatu/\$FILE/OEOK-NAP_cely_20170127.pdf

[4] MCFADDEN, D.L. Conditional logit analysis of qualitative choice behavior. In: ZAREMBKA, P. ed. Frontiers in Econometrics. New York: Academic Press, 1974, p. 105-142.

[5] HUNT, A., PARDY, J., FINUS, M., ŠČASNÝ, M., ZVĚŘINOVÁ, I., and MARTíNKOVÁ, Z. The Economics of Climate Change Adaptation: Deliverable 2.1., Defining the opportunity costs of adaptation. [online]. 2016. Dostupné z: www.econadapt.eu

[6] STEENTJES, K , PIDGEON, N. F, POORTINGA, W CORNER, A.J, ARNOLD A et al European Perceptions of Climate Change: Topline findings of a survey conducted in four European countries in 2016. Cardiff: Cardiff University, 2017.

[7] MAHMUD, S. Essays on the Private Defensive Strategies against Storm Damages given the Presence of Public Programs and Natural Storm Protection Barriers. 2011. Disertační práce. University of Wyoming United States.

8] RYFFEL, A.N., RID, W., and GRETT-REGAMEY, A. Land use trade-offs for flood protection: A choice experiment with visualizations. Ecosystem Services [online], 2014, vol. 10, p. 111-123. ISSN 22120416. Dostupné z: doi:10.1016/j.ecoser.2014.09.008

[9] TANEJA, G., PAL, B., JOSHI, P.K., AGGARWAL, P., and Tyagi, N.K. Farmerss Preferences for ClimateSmart Agriculture: An Assessment in the Indo-Gangetic Plain. SSRN Electronic Journal [online], 2014 [vid. 2015-07-02]. ISSN 1556-5068. Dostupné z: doi:10.2139/ssrn.2420547

[10] ALCON, F., TAPSUWAN, S., BROUWER, R., and DE MIGUEL, M.D. Adoption of irrigation water policies to guarantee water supply: A choice experiment. Environmental Science \& Policy [online]. 2014, vol. 44 p. 226-236. ISSN 14629011. Dostupné z: doi:10.1016/j.envsci.2014.08.012

[11] LANDAUER, M., PRÖBSTL, U., and HAIDER, W. Managing cross-country skiing destinations under the conditions of climate change - Scenarios for destinations in Austria and Finland. Tourism Management [online], 2012, vol. 33, No. 4, p. 741-751. ISSN 02615177. Dostupné z: doi:10.1016/j. tourman.2011.08.007

[12] BÉLANGER, D. and GOSSELIN, P. Climate Change in Southern Quebec: Perceptions of the Genera Population and Suggestions for Future Adaptation. In: Changements climatiques au Québec méridiona: perceptions de la population générale et suggestions d'adaptations futures. B.m.: Institut national de santé publique du Québec, 2007

[13] WANG, Y. Valuation of irrigation water in southern Alberta a stated preference approach. Ottawa, 2010 Library and Archives Canada = Bibliothèque et Archives Canada

[14] GRIFFIN, R.C. and MJELDE, J.W. Valuing Water Supply Reliability. American Journal of Agricultural Economics [online], 2000, vol. 82, No. 2, p. 414-426. ISSN 00029092, 14678276. Dostupné z: doi:10.1111/0002-9092.00035

[15] CALIFORNIA URBAN WATER AGENCIES. The value of water supply reliability: results of a contingent valuation survey of residential customers. 1994

\section{Autoři}

Mgr. Iva Zvěřinová

凶iva.zverinova@czp.cuni.cz

Mgr. Milan Ščasný, Ph.D.

凶milan.scasny@czp.cuni.cz

Mgr. Zuzana Rajchlová

凶zuzana.rajchlova@czp.cuni.cz

Univerzita Karlova, Centrum pro otázky životního prostředí

Přispěvek prošel lektorským řízením. 


\section{CZECH CITIZENS' PREFERENCES OF}

\section{ADAPTATION MEASURES TO LIMIT DAMAGES FROM FLOODS AND DROUGHTS}

\section{ZVERINOVA, I.; SCASNY, M.; RAJCHLOVA, Z.}

Charles University, Environment Centre

Keywords: climate change adaptation - hard measures -

nature-based measures - discrete choice experiments - willingness to pay

The aim of the research is to examine attitudes and preferences of the Czechs for adaptation measures reducing impacts of floods and droughts. In spring 2016, we conducted a survey on a representative sample of the Czech population (3,666 respondents). More than half of the respondents expect that their households will be exposed to the effects of droughts and heat waves more often in the next 10 years. Changes in forest management (72\%), agricultural land management ( $69 \%)$, and use of waste and rainwater (63\%) were the most supported measures at the national level. Creation of wetlands was also very popular. Respondents were most critical of introduction of taxes or fees. The Czechs are willing to pay part of the costs of drought and flood damage reduction. The average household willingness to pay for adaptation measures reducing impacts of droughts is CZK 1,000 a month and of floods is CZK 923. Respondents are willing to pay for costs of technical measures, but their acceptability declines as their share increases at the expense of natural measures. 